\title{
THEORY PLANNED BEHAVIOR DAN PENGARUHNY TERHADAP KINERJA MAHASISWA DENGAN COORPORATIVE LEARNING TIPE JIGSAW SEBAGAI VARIABEL MODERATING DI FEB UNIVERSITAS MUHAMMADIYAH SURABAYA
}

\author{
Siti Salbiyah \\ Universitas Muhammadiyah Surabaya
}

\begin{abstract}
The Theory of Planning Behavior Research (TPB) has a significant role in the performance of students with Jigsaw Cooperative Learning as a moderating variable. In this study, Cooperative Learning Type Jigsaw was chosen as moderating the relationship between Planned Behavior Theory (TPB) and student acquisition. The population used was 313 third semester students of management and accounting study program of FEB UM Surabaya. The sampling technique used is the Issac and Michael Tables to determine the sample size of 147 respondents. The analysis technique used is a Moderated Regression Analysis (MRA) analysis tool. The results of this research show (1) The Theory of Planned Behavior (TPB) does not significantly influence student performance, (2) Jigsaw Cooperative Learning does not moderate the effect of the Planned Behavior Theory (TPB) on student performance.
\end{abstract}

Kata kunci :Theory Planned Behavior, Cooperative Learning Tipe Jigsaw, kinerja mahasiswa Korespondensi :sitisalbiyah51@gmail.com

\section{PENDAHULUAN}

Pendidikan adalah usaha sadar dan terencana untuk mewujudkan suasana belajar dan proses pembelajaran agar peserta didik secara aktif mengembangkan potensi dirinya untuk memiliki kekuatan spiritual keagamaan, pengendalian diri, kepribadian, kecerdasan, akhlak mulia serta ketrampilan yang diperlukan dirinya, masyarakat, bangsa dan Negara.

Belajar adalah proses yang dilakukan seumur hidup. Belajar berkelanjutan dapat menambah pengetahuan yang lebih banyak, pemahamannya lebih luas dan berwawasan yang lebih baik tentang kehidupan akan menjadikan seseorang yang lebih baik, bertanggung jawab dan menjadi warga negara yang jujur. Dalam proses pembelajaran, siswa adalah pusat pendidikan (Lumpkin,2007). Peraturan Presiden No. 8 Tahun 2012 tentang Kerangka Kualifikasi Nasional Indonesia (KKNI) Pasal 35 ayat 2 tentang Rumusan Standart Kopetensi Lulusan (SKL) yang dinyatakan dalam capaian pembelajaran Lulusa (CPL) terdiri dari aspek sikap, penegtahuan, ketrampilan Umum dan, dan ketrampilan khusus yang dirumuskan berdasarkan SN Dikti dan deskriptor KKNI sesuai dengan jenjangnya. Sikap berarti sikap bertanggungjawab atas pekerjaan di bidang keahlian secara mandiri. Ketrampilan Umum artinya mampu menunjukkan kinerja mandiri, bermutu dan terukur. Ketrampilan khusus artinya mampu berkomunikasi secara efektif, mampu menggunakan teknik ketrampilan dan pembaruan ilmiah. Sementara pengetahuan mengandung makna konsep teoritis di bidang keilmuannya dan menguasai pengetahuan tentang isu-isu masa kini dan berfikir kreatif dan inovatif.

Capaian Pembelajaran Mata Kuliah (CPMK) Perekonomian Indonesia adalah; 1). P1. Menguasai konsep-konsep, hukumhukum dan teori-teori dan penjabaran empiris mengenai seluk beluk perekonomian nasional. 2). K3. Mampu mengidentifikasi 


\section{Balance: Economic, B usiness, Management, and Accounting J ournal}

Vol. XVII No. 1 | Bulan J anuari Tahun 2020

karakteristik-karakeristik penting dari proses pembangunan ekonomi di Indonesia transfer knowledge dan menulis karya ilmiah tentang seluk beluk perekonomian nasional . 3). S3. Mampu mendiskusikan berbagai isu-isu yang berkaitan dengan seluk beluk perekonomian nasional. 4). M1. Mampumelakukananalisis kebutuhan (needs assessment): Swot dalam mendiskusikan isue-isue yang berkaitan dengan seluk beluk perekonomian nasional.

Dalam rangka merealisasikan capaian pembelajaran mata kuliah Perekonomian Indonesia tersebut diperlukan proses pembelajaran yang aktif, kreatif dan inovatif. Pembelajaran kooperatif adalah salah satu jenis pendekatan pembelajaran yang berpusat pada mahasiswa, banyak literatur yang mendokumentasikan bahwa pendekatan ini efektif dalam membantu siswa pada proses pembelajaran, komunilkasi yang efektif dan kemampuan dalam hal pemahaman pengetahuan, dan mempromosikan sikap positif mahasiswa terhadap pembelajaran mereka sendiri (Tran et.al. 2012). Penerapan model pembelajaran kooperatif tipe Jigsaw diharapkan dapat meningkatkan hasil belajar, meningkatkan keaktifan belajar, meningkatkan minat belajar dan meningkatkan hasil belajar kompetensi pengetahuan, sikap dan ketrampilan mahasiswa, yang pada giliran berikutnya meningkatkan mutu pendidikan di kelasnya.

Penelitian ini mencoba menjelaskan faktor niat mahasiswa dengan dimoderasi oleh pembelajaran kooperatif tipe Jigsaw dalam mata kuliah Perekonomian Indonesia berdasarkan Theory of Planned Behavior. Menurut Ajzen (1991), "Niat seseorang dilakukan oleh tiga kontruks yaitu Attitude Toward Behavior (Sikap terhadap perilaku), Subjective Norm (Norma subjektif) dan Perceived Behavioral Control (Kontrol perilaku persepsian)". TPB sangat sesuai untuk digunakan dalam menjelaskan berbagai perilaku kewirausahaan. Sebagaimana dikatakan Ajzen (1991) bahwa TPB is suitable to explain any behavior which requires planning, such as entrepreneurship (TPB cocok untuk menjelaskan perilaku apapun yang memerlukan perencanaan, seperti kewirausahaan).

Menyadari pentingnya inovasi model pembelajaran dalam hal ini adalah model pembelajaran kooperatif tipe Jigsaw, maka perlu dilakukan penelitian dengan judul :" Theory of Planned Behavior dan Pengaruhnya Terhadap Kinerja Mahasiswa dengan Cooperative Learning Tipe Jigsawsebagai Variabel Moderating di FEB Universitas Muhammadiyah Surabaya”.

\section{METODE PENELITIAN}

Penelitian ini merupakan penelitian kuantitatif dengan menggunakan explanatory research untuk membuat gambaran mengenai situasi atau fenomena. Berdasarkan data skunder ini diperoleh data populasi sebanyak 313 responden adalah mahasiswa yang aktif mengikuti perkuliahan Perekonomian Inndonesia semester gasal 2019/2020. Teknik pengambilan sampel penelitian ini menggunakan tabel Isaac dan Michael, dengan N 320 pada signifikansi $10 \%$ diperoleh jumlah sampel 147 responden.

Definisi operasional variabel

\section{Theory Planned Behavior (X)}

Theory of Planned Behavior (TPB) merupakan perluasan dari TRA (Theory of Reasoned Action) TRA menjelaskan bahwa niat seseorang terhadap perilaku dibentuk oleh dua faktor yaitu attitude toward the behavior dan subjective norm (Fishbein dan Ajzen, 1975), sedangkan Theory of Planned Behavior (TPB) ditambahkan satu faktor yaitu perceived behavior control (Ajzen, 1991). 1) Attitud (Sikap), sikap perilaku mengacu pada tingkat dimana seseorang mempunyai penilaian evaluasi apakah perilaku itu baik atau kurang baik. 2) Subjective Norma, norma subjektif mengacu pada hubungan tekanan sosial merasa untuk 


\section{Balance: Economic, B usiness, Management, and Accounting J ournal Vol. XVII No. 1 | Bulan J anuari Tahun 2020}

melakukan atau tidak melakukan perilaku. 3) Perceived behavior control, mengacu pada mudah atau sulit melalukan perilaku dan diasumsikan untuk merefleksikan pengalamam masa lalu atau antisipasi halangan serta rintangan (Ajzen dalam $\mathrm{Li}$ Wei, 2006)

2. Kinerja berkaitan dengan tugas pekerjaan, tugas atau tujuan, yang meliputi 5 indikator yaitu Kualitas, Kuantitas, Tanggung jawab, Kerja sama dan Inisiatif

3. Pembelajaran Kooperatif Tipe Jigsaw (Z)

Menurut Rusman (2012) pada dasarnya dalam model pembelajaran kooperatif tipe jigsaw ini guru membagi satuan informasi yang besar menjadi komponen-komponen lebih kecil. Selanjutnya guru membagi siswa kedalam kelompok kecil, belajar kooperatif yang terdiri dari empat orang siswa sehingga setiap anggota bertanggungjawab terhadap penguasaan setiap komponen/subtopik yang ditugaskan guru dengan sebaik-baiknya. Siswa dari masing-masing kelompok yang bertanggungjawab terhadap subtopik yang sama membentuk lagi yang terdiri atas dua atau tiga orang.

Data akvitas belajar mahasiswa diamati dengan indikator (1). Antusiasme mahasiswa dalam mengikuti pembelajaran (2) Interaksi mahasiswa dengan dosen (3). Interaksi mahasiswa dengan mahasiswa (4) Kerjasama kelompok (5) Aktivitas mahasiswa dalam diskusi kelompok (6) Usaha mahasiswa dalam mengikuti pembelajaran (7) Partisiasi mahasiswa dalam menyimpulkan materi pelajaran.

Dalam penerapan model pembelajaran kooperatif tipe Jigsaw mengedepankan keaktifan mahasiswa untuk mencapai tujuan pembelajaran yang telah ditentukan yakni perubahan dalam aspek kognitif, afektif, psikomotor dan kemampuan managerial pada mata kuliah Perekonomian Indonesia, maka ditentukan langkah-langkah pembelajaran sebagai berikut:

1. Dosen menjelaskan tujuan dan model pembelajaran yang tersusun dalam Kontrak Perkuliahan mata kuliah Perekonomian

2. Mahasiswa dibagi beberaopa kelompok (tiap kelompok beranggotan 5- 6 orang).

3. Materi pembelajaran diberikan kepada mahasiswa dalam bentuk teks yang telah dibagi-bagi menjadi beberapa sub bab.

4. Setiap anggota kelompok membaca subsub bab yang telah ditugaskan dan bertanggungjawab untuk mempelajarinya dan membuat ringkasan dalam PPT untuk dipresentasikan di depan kelompok yang lain berdasarkan urutan materi pembelajaran.

5. Pembelajaran dilakukan dengan teknik presentasi, diskusi dan tanya jawab.

6. Pembelajaran diikuti oleh satu kelompok sebagai prenyaji materi, 1 kelompok sebagai penganggah dan kelompok lain bertugas sebagai reviewer dengan masingmasing menggunakan prinsip 4C (Critical thinking, creative, communicative, dan collaborative).

7. Kelompok penyaji materi akan mendapatkan masukan dari para penyanggah dan para reviuwer atas kekurang lengkapnya materi, model PPT maupun gaya presentasi di depan kelas.

8. Langkah akhir pembelajaran dosen menjelaskan materi yang belum terjelaskan dan belum tersampekan dalam proses pembelajaran dan membuat kesimpulan materi yang telah disajikan.

9. Dosen menutup pembelajaran dengan memimpin do'a penutup.

\section{Teknik Analisis dan Uji Hipotesis}

Pengujian terhadap hipotesis dilakukan dengan menggunakan uji startistik $F$ dan $t$, yaitu pengujian koefisien untuk mengetahui pengaruh baik secara simultan maupun parsial dari setiap variabel independen terhadap variabel dependennya. 
Vol. XVII No. 1 | Bulan J anuari Tahun 2020

Dan untuk menguji pengaruh variabel moderasi digunakan MRA (Moderated Regression Analysis) dengan menggunakan rumus persamaan regresi:

$Y=a+b_{1} X+b_{2} Z+b_{3}|X-Z|+e$

\section{HASIL PENELITIAN}

Penelitian ini menganggkat permasalahan mengenai " Theory Planned Behavior Dan Pengaruhnya terhadap Kinerja Mahasiswa dengan Pembelajaran Kooperatif Tipe Jigsaw Sebagai Variabel Moderating Pada FEB UMSurabaya". Penyebaran kuesener dilakukan pada waktu perkuliahan berakhir pada tatap muka ke 14 sebayak 156 responden. Dari hasil pengolahan data diketahui sebanyak 26 kuesioner tidak lengkap pengisian datanya, sehingga tidak diikut sertakan dalam analisis data. Sisanya sebanyak 130 data responden yang memenuhi syarat untuk dilakukan identifikasi berdasarkan jenis kelamin, umur, asal sekolah, dan pernah mengikuti proses pembelajaran mata kuliah perekonomian Indonesia.

1. Karakteristik Responden Berdasarkan Jenis Kelamin.

Tabel. 1 Karakteristik Responden Berdasarkan Jenis Kelamin

\begin{tabular}{ccc}
\hline $\begin{array}{c}\text { Jenis } \\
\text { Kelamin }\end{array}$ & Frekuensi & Presentase \\
\hline Laki-laki & 39 & $30 \%$ \\
\hline Perempuan & 91 & $70 \%$ \\
\hline Total & 130 & $100 \%$ \\
\hline \multicolumn{3}{c}{ Sumber : Data diolah }
\end{tabular}

Berdasarkan tabel diatas, dapat dilihat responden yang mendominasi adalah responden berjenis kelamin perempuan sebanyak 91 mahasiswa atau sebesar $70 \%$, dan yang paling sedikit adalah responden berjenis kelamin lakilaki sebanyak 39 responden atau sebanyak 39 resonden atau sebanyak $30 \%$.
2. Karakteritik Responden Berdasarkan Umur

Tabel 2Karakteritik Responden Berdasarkan Umur

\begin{tabular}{ccc}
\hline Usia & Frekuensi & Prosentase \\
\hline$<20$ th & 82 & $63 \%$ \\
\hline $20-25$ th & 45 & $35 \%$ \\
\hline $26-30$ th & 3 & $2 \%$ \\
\hline $31-35$ th & 0 & $0 \%$ \\
\hline Total & 130 & $100 \%$ \\
\hline \multicolumn{3}{c}{ Sumber : Data diolah }
\end{tabular}

Tabel tersebut menunjukkan paling banyak mendominasi adalah responden yang berumur $<20$ tahun sebanyak 82 responden atau sebanyak $63 \%$, dan paling sedikit sebanyak 3 responden atau sebanyak $2 \%$ responden berumur antara 26 sd 30 tahun.

3. Karakteritik Responden Berdasarkan Asal Sekolah

Tabel 3Karakteritik Responden Berdasarkan

\begin{tabular}{ccc}
\multicolumn{3}{c}{ Asal Sekolah } \\
\hline Asal Sekolah & Frekuensi & Prosentase \\
\hline SMA/SMK & 118 & $90,7 \%$ \\
\hline D1 / D2 & 4 & $3 \%$ \\
\hline D 3 & 2 & $1,5 \%$ \\
\hline S 1 & 6 & $4,8 \%$ \\
\hline Total & 130 & $100 \%$ \\
\hline \multicolumn{3}{c}{ Sumber : Data diolah }
\end{tabular}

Tabel tersebut menggambarkan bahwa frekuensi tertinggi responden berdasarkan asal sekolah adalah 118 responden atau sebanyak 90,7\% responden berpendidikan asal sekolah SMA/SMK dan yang paling rendah adalah 2 responden atau 1,5 \% berpendidikan D3 atau mahasiswa tranfer dari Perguruan Tinggi lain.

4. Karakteristik Responden Berdasarkan Peserta Mata Kuliah Perekonomian Indonesia 


\begin{tabular}{ccc}
\hline \hline \multicolumn{3}{c}{ Tabel 4Karakteristik Responden Berdasarkan } \\
Peserta Mata Kuliah Perekonomian Indonesia
\end{tabular}

Tabel tersebut menunjukkan bahwa seluruh responden sebanyak 130 orang adalah mahasiswa yang aktif mengikuti pembelajaran mata kuliah Perekonomian Indonesia dengan model pembelajaran kooperatif tipe Jigsaw.

Hasil uji hipotesis pada penelitian ini terdapat dua analisis dan dua uji hipotesis adalah sebagai berikut :

Pengaruh Theory Planned Behavior (X) Terhadap Kinerja Mahasiswa (Y) Dengan Cooperative Learning Tipe Jigsaw (Z) sebagai Variabel Moderating.

Tabel . 10Hasi uji F (ANOVA)

ANOVA $^{\mathrm{a}}$

\begin{tabular}{|c|c|c|c|c|c|c|}
\hline \multicolumn{2}{|c|}{ Model } & Sum of Squares & $\mathrm{df}$ & Mean Square & $\mathrm{F}$ & Sig. \\
\hline$\overline{1}$ & Regression & 11.533 & 3 & 3.844 & 15.715 & $.000^{\mathrm{b}}$ \\
\hline & Residual & 30.823 & 126 & .245 & & \\
\hline & Total & 42.356 & 129 & & & \\
\hline
\end{tabular}

a. Dependent Variable: Y

b. Predictors: (Constant), AbsX_Z, X, Z

Sumber: Data diolah

Berdasarkan tabel diatas dapat diketahui nilai $\mathrm{F}$ hitung yang diperoleh dari pengolahan data adalah 15.715 dengan tingkat siginifikansi sebesar 0,000 atau lebih kecil 0.05 maka Ho ditolak dengan $\mathrm{Ha}$ diterima, yang artinya model yang digunakan adalah signifikan atau cocok untuk mengetahui pengaruh theory planned

behavior $(X)$, cooperative learning tipe jigsaw $(Z)$ terhadap kinerja mahasiswa $(\mathrm{Y})$.

Uji $t$ dapat digunakan untuk mengetahui signifikan atau tidaknya pengaruh secara parsial theory planned behavior $(X)$, cooperative learning tipe jigsaw $(Z)$ terhadap kinerja mahasiswa (Y).

Tabel 11. Hasil Uji t

\begin{tabular}{|c|c|c|c|c|}
\hline Variabel & t hitung & Sig. & Kriteria Pengujian & Kesimpulan \\
\hline $\begin{array}{ll}\text { Theory } & \text { Planned } \\
\text { Behavior }(X) & \end{array}$ & 1.408 & 0.162 & $\begin{array}{l}\text { Jika nilai probabilitas }(\mathrm{P} \\
\text { value)/signifikan }>0.05\end{array}$ & $\begin{array}{l}\text { Ho diterima dan } \mathrm{Ha} \\
\text { ditolak }\end{array}$ \\
\hline $\begin{array}{l}\text { Cooperative Learning } \\
\text { Tipe Jigsaw }(Z)\end{array}$ & 3.216 & 0.002 & $\begin{array}{l}\text { maka Ho diterima dan } \mathrm{Ha} \\
\text { ditolak }\end{array}$ & $\begin{array}{l}\text { Ho ditolak dan } \mathrm{Ha} \\
\text { diterima }\end{array}$ \\
\hline $\begin{array}{lr}\text { Interaksi } & \text { antara } \\
\text { variabel } & \text { Theory } \\
\text { Planned Behavior dan } \\
\text { Cooperative Learning } \\
\text { Tipe Jigsaw (X_Z) }\end{array}$ & 1.437 & 0.153 & $\begin{array}{l}\text { Jika nilai probabilitas } \\
(\mathrm{P} \text { value }) / \text { signifikan } \\
<0.05 \text { maka Ho ditolak } \\
\text { dan Ha diterima }\end{array}$ & $\begin{array}{l}\text { Ho diterima dan } \mathrm{Ha} \\
\text { ditolak }\end{array}$ \\
\hline
\end{tabular}

Sumber: Data diolah 
Hasil uji $\mathrm{t}$ menunjukkan bahwa variabel Theory Planned Behavior (X), berpengaruh tidak signifikan terhadap kinerja mahasiswa semester 3 Universitas Muhammadiyah Surabaya mengenai model pembelajaran Cooperative Learning Tipe Jigsaw (Z). Hal ini ditunjukkan dari nilai t hitung sebesar 0.148 dengan signifikansi 0.162 yang lebih besar dari 0.05 . Berdasarkan hasil tersebut maka hipotesis $\mathrm{H} 1$ yang menyatakan bahwa Theory Of Planned Behavior(TPB) berpengaruh secara signifikan terhadap kinerja mahasiswa FEB UMSurabaya ditolak, sehingga dalam penelitian ini memperlemah TPB dalam mempengaruhi kinerja mahasiswa bukan memperkuat.

Untuk hasil uji t menunjukkan pula bahwa Cooperative Learning Tipe Jigsaw (Z) tidak memoderasi pengaruh Theory Planned Behavior $(X)$ terhadap kinerja mahasiswa. Hal ini ditunjukan dari dari nilai t- hitung sebesar 1.437 dengan signifikansi 0.153 yang lebih besar dari 0.05. Berdasarkan hasil tersebut maka hipotesis yang menyatakan bahwa Berdasarkan hasil uji t menunjukan pula bahwa Cooperative Learning Tipe Jigsaw (Z) tidak memoderasi pengaruh Theory Planned Behavior (X) terhadap kinerja mahasiswa, Cooperative Learning Tipe Jigsaw (Z) mempunyai pengaruh terhadap kinerja mahasiswa jika sebagai variabel bebas bukan sebagai variabel moderating, sehingga Model pembelajaran Cooperative Learning Tipe Jigsaw dalam penelitian ini memperlemah TPB dalam mempergnaruhi kinerja mahasiswa bukan memperkuat.

\section{PEMBAHASAN}

Berdasarkan hasil pengujian secara statistik menunjukkan bahwa Theory of Planned Behavior(TPB) berpengaruh tidak signifikan terhadap kinerja mahasiswa. Hal ini disebabkan bahwa ternyata TPB yang terdiri: sikap, norma subjektif dan control perilaku yang dirasakan saja tidak bisa menjadi satu-satunya faktor yang mempengaruhi kinerja mahasiswa. Faktor lain selain TPB dimungkinkan bisa mempengaruhi kinerja mahasiswa antara lain misalnya; motivasi belajar, perilaku belajar, minat belajar dan tujuan belajar. Hal ini sejalan dengan bahwa: Teori tindakan beralasan dan teori perilaku yang direncanakan memiliki beberapa keterbatasan dalam memprediksi perilaku, (Werner, 2004). Keterbatasan pertama adalah bahwa faktor keinginan tidak terbatas pada sikap, norma subjektif, dan persepsi pengendalian perilaku, (Ajzen I, 1991). Keterbatasan kedua adalah penelitian empiris menunjukkan bahwa hanya $40 \%$ dari varian perilaku dapat dijelaskan dengan menggunakan teori tindakan beralasan atau teori perilaku direncanakan, (Ajzen 1991:Werner 2004). Keterbatasan ketiga adalah kemungkinan ada kesenjangan besar waktu antara penilaian keinginan perilaku dan perilaku yang sebenarnya yang dinilai, dalam selang waktu itu keinginan individu bisa berubah, (Werner, 2004) . Keterbatasan keempat adalah bahwa kedua teori tindakan beralasan dan teori perilaku direncanakan adalah model prediksi yang memprediksi tindakan individu berdasarkan kriteria tertentu, namun individu tidak selaku berperilaku seperti yang diperkirakan oleh kriteria, (Werner, 2004).

Berdasarkan uji statistik selajutnya, Cooperative Learning tipe Jigsaw ternyata tidak memoderasi variabel bebas yaitu Theory of Planned Behavior(TPB) dalam mempengaruhi kinerja mahasiswa. Hal ini dimungkinkan disebabkan karena Cooperative Learning tipe Jigsaw karena tidak menjadi satu-satunya faktor yang mempengaruhi Theory of Planned 
Behavior(TPB) dalam mempengaruhi kinerja mahasiswa, sehingga Cooperative Learning tipe Jigsaw dalam penelitian ini juga memperlemah TPB dalam mempengaruhi kineja mahasiswa bukan memperkuat. Hal tersebut bisa disebakan oleh karena mahasiswa prodi manajemen dan akuntansi semester tiga FEB UMSurabaya sebagai sampel dalam penelitian ini belum menganggap penting bahwa memahami konsep dan manfaat dari strategi pembelajaran kooperastif tipe Jigsaw penting, sehingga mempelajari mata kuliah perekonomian Indonesia dengan model pembelajaran kooperatif tipe Jigsaw tidak menarik sebagai suatu kegiatan dalam meningkatkan kualitas hasil belajar yang dalam hal ini adalah kinerja mahasiswa. Kemungkinan juga belum dianggap bahwa model pembelajaran kooperatif tipe Jigsaw dianggap tidak begitu penting bagi mahasiswa selain hanya sebagai latihan bicara di depan kelas. Selain dilihat dari latar belakang pendidikan yang sangat bervariasi , hal ini juga mungkin menjadi penyebab tingkat pemahaman dan ketrampilan yang dimiliki juga berbeda. Selain itu perlu diketahui juga bahwa sebagian besar mahasiswa adalah lulusan SMA/SMK sebanyak 118 mahasiswa atau 90,7\% berjenis kelamin perempuan sebanyak 91 mahasiswa atau $70 \%$ dan sebanyak 82 mahasiswa atau $63 \%$ berumur dibawah 20 tahun, hal ini berarti masuk kelompok remaja, yang kondisi psikologisnya masih labil, dan belum fokus dalam memperjuangkan tujuan belajarnya. Selain itu juga masing-masing kelompok mahasiswa rata-rata hanya mendapat giliran sekali selama satu semester berperan sebagai kelompok ahli dalam diskusi pada proses pembelajaran kooperatif tipe Jigsaw, sehingga kemampuan kognitif, afektif dan psikotor dan kemampuan managerialnya belum tereksplor dengan optimal. Disisi lain hasil penelitian juga menunjukkan bahwa Cooperative Learning tipe Jigsaw mempunyai pengaruh terhadap kinerja mahasiswa jika sebagai variabel bebas bukan sebagai variabel moderating. Oleh karena itu perlu dilakukan penelitian lebih lanjut tentang Cooperative Learning tipe Jigsaw sebagai variabel bebas.

\section{SIMPULAN}

Dari hasil penelitian dapat ditarik kesimpulan bahwa Theory of Planned Behavior (TPB) berpengaruh tidak sigfnifikan terhadap kinerja mahasiswa FEB UMSurabaya. Hal ini bisa dimungkinkan tidak memiliki faktor pengendali yakni faktor internal yang antara lain ketrampilan, kemampuan, informasi, emosi, stress., dan lain-lain. Faktor-faktor eksternal meliputi situasi dan faktor-faktor lingkungan yang mendukung . (Mahyarni). . Hal ini bisa saja disebabkan karena banyak faktor lainnya yang tidak teramati dalam penelitian ini. Terdapat faktor lain yang mungkin bisa mempengaruhi kinerja mahasiswa selain TPB seperti : 1). Faktor keinginan tidak terbatas pada sikap, norma subjektif, dan persepsi pengendalian perilaku, 2). Hanya $40 \%$ dari varian perilaku dapat dijelaskan dengan menggunakan IPB, 3). Ada kesenjangan besar waktu antara penilaian keinginan perilaku dan perilaku yang sebenarnya yang dinilai, dalam selang waktu itu keinginan individu bisa berubah, 4). Teori tindakan beralasan dan teori perilaku direncanakan adalah model prediksi yang memprediksi tindakan individu berdasarkan kriteria tertentu, namun individu tidak selalu berperilaku seperti yang diperkirakan oleh kriteria. (Werner, 2004).

Saran 
Bagi mahasiswa umumnya disarankan untuk lebih serius dalam meningkatkan kinerja mahasiswa, dalam mengikuti proses pembelajaran dalam rangka meningkakan kinerja mahasiswa, dengan membentuk kelompok belajar, yang kegiatannya diarahkan untuk menunjang capaian pembelajaran dalam ranah kognitif, afektif, psikomotor melalui diskusi-diskusi kelompok dan kemampuan manajerial. Bagi para pengajar disarankan mampu memilih model pembelajaran yang sesuai dengan Capaian Pembelajaran Semester yang telah direnckan, termasuk penggunaan model pembelajaran kooperatif tipe Jigsaw pembelajarannya maupun penelilihan tindakan kelas sebagai penunjang jabatan fungsional akademiknya.

\section{DAFTAR PUSTAKA}

Ajzen, Icek. (1988). Attitudes personality, and behavior. Milton Keynes: Open University Press dan Chicago, IL: Dorsey Press.

------- (1991). The Theory of Planned Behavior: Organizational Behavior and Human Decision Processes. University of Massachusetts at Amherst. 50:179211.

------- (2005). Attitude Personality and Behavior. New York. USA: Open University Press.

Ajzen, I., (2006). Constructing a TPB Questionnaire: Conceptual and Methodological Considerations. [Online] Available at: http://www.people.umass.edu[Accessed 27 2015]

Aronson sponsors a website with important information about his methods at http://www.jigsaw.org/

Corsini, Ray. (2002). The Dictionary of Psychology. London: Brunner/Rout Ledge.

Cruz, L, Suprapti., \& Yasa., 2015. E- Jurnal Ekonomi dan Bisnis. Aplikasi Theory Of Planned Behavior Dalam
Membangkitkan Niat Berwirausaha Bagi Mahasiswa Fakultas Ekonomi UNPAZ. DILI Timor Leste.

Fishbein, M., \& Ajzen, I,, 1975. Belief, Attitude, Intention, and Behavior: An Introduction to Theory and Research, Reading. MA: Addison-Wesley.

Ghozali, I. 2005. Aplikasi Analisis Multivariat Dengan Program SPSS. Universitas Dipenogoro. Semarang.

Ghozali, I. 2013. Aplikasi Analisis Multivariat Dengan Program SPSS. Universitas Dipenogoro. Semarang.

Grid, A., \& J, J, Bagraim., 2008. South African Journal of Psychology. The Theory Of Planned Behavior as Predictor of Entrepreneurial Intentamongst Final-year University Student.

https://idthesis.com/teori-lengkap-tentangtheory-planned-behavior-tpb.

Ismal, V, Y., \& Zain, E., 2008. Peranan Sikap, Norma Subjektif, dan Perceived Behavior Control terhadap Intensi Pelajar SLTA untuk Memilih Fakultas Ekonomi. Jurnal Ekonomi dan Bisnis Vol. 5 No. 3, Desember 08.

Yuliana. (2004). Pengaruh Sikap pada Pindah Kerja, Norma Subjektif, Perceived Behavioral Control pada Intensi Pindah Kerja pada Pekerja Tehnologi Informasi. Phronesis: Jurnal Ilmiah Psikologi Terapan 6, 1-18.

Kosasih., Natalia., dan Sri Budiani., 2007. Pengaruh Knowledge Management Terhadap Kinerja Karyawan: Studi Kasus Departemen Front Office Surabaya Plaza Hotel. Jurnal Manajemen Perhotelan. Vol. 3. No. 2 pp 80-88.

Li, Wei. 2006. Entrepreneurial Intention Among International Student: Testing a model of entrepreneural intention. Journal University of Illinois at Urbana Champaign, 217-721-9969.

Lie A. 2010. Cooperative Learning. Jakarta: Penerbit Grasindo.

Lumpkin, A., 2007. Caring teachers the key to student learning. Kappa Delta $\mathrm{Pi}$ Record. Vol. 43, Issue 4, pp. 158-160 
Balance: Economic, Business, Management, and Accounting J ournal Vol. XVII No. 1 | Bulan J anuari Tahun 2020 